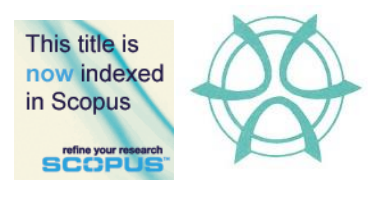

PLANNING MALAYSIA:

Journal of the Malaysian Institute of Planners

VOLUME 16 ISSUE 2 (2018), Page 207 - 216

\title{
FACTORS INFLUENCING PARENTS IN SELECTING SCHOOL FOR CHILDREN WITH SPECIAL EDUCATION NEEDS
}

\author{
Muhammad Faris Abdullah', Ainul Ashiqin Ahmad Shuhaimi ${ }^{2}$, Mariana \\ Mohamed Osman ${ }^{3}, \&$ Noor Suzilawati Rabe ${ }^{4}$ \\ ${ }^{1,2,3,4}$ Kulliyyah of Architecture and Environmental Design, \\ INTERNATIONAL ISLAMIC UNIVERSITY MALAYSIA
}

\begin{abstract}
Equal access to education is an essential element in achieving community wellbeing, hence it is crucial that the educational facilities to be equally accessible to children with special education needs. In Malaysia, one of the special education programme provided in mainstream public schools is the Program Pendidikan Khas Integrasi (PPKI). The programme is an effort towards inclusive education. The objective of this study includes: (i) to analyse the factors influencing the decision of parents in selecting school for their special children, and (ii) to assess the issues and problems faced by parents in selecting schools for their children with special needs. The study determines parents' criteria in selecting school for their children with SEN among 134 parents of children in PPKI via questionnaire survey. Semi-structured interview was conducted among 12 teachers of PPKI, and the findings from the interview were used to validate the survey findings. Findings from these two methods were consolidated. Result shows that school selection for children with special needs are greatly associated with the school facility. The paper will benefit the local authority in planning for educational facility, as well as special needs children with regards to the educational facility for special education provision in a community.
\end{abstract}

Keywords: special education, educational facilities, factors, parental influence, Special Education Integrated Programmes 
Muhammad Faris Abdullah, Ainul Ashiqin Ahmad Shuhaimi, Mariana Mohamed Osman, \& Noor Suzilawati Rabe Factors Influencing Parents in Selecting School for Children with Special Education Needs

\section{INTRODUCTION}

The Malaysian education system aims to be more accessible and comprehensive especially for children with special education needs. These children have the rights to formal education just like every other children. According to the Special Education Regulations 2013, special education is an education programme that is either provided in special schools or in mainstream schools with special education integrated programme/ Program Pendidikan Khas Integrasi (PPKI) or inclusive programmes at different levels such as preschools, primary, secondary and the higher secondary.

Special education programme is designed to meet the needs and learning capacity of people with disability - those with visual impairment, hearing impairment, speech difficulties, physical disabilities, multiple disabilities and learning disabilities such as autism, Down syndrome, attention deficit hyperactivity disorder, and dyslexia, all which restricts their full participation in the society. Pupils with special education needs require additional support in overcoming their challenges in self-development. The challenges faced by these pupils should explain the rationale behind parents' preferences in selecting schools for their children. The objective of this study includes: (i) to analyse the factors influencing parents' decision in selecting school for their special needs children, and (ii) to assess the issues faced by parents in selecting schools for their special needs children.

\section{SPECIAL EDUCATION}

It is the responsibility of the Ministry of Education (MOE) to provide access to education for all children including those with special education needs. The Education Act 1996 requires the MOE to provide special education in special schools or in designated primary and secondary schools, as an integrated or inclusive programmes. The special education regulation is applicable in government schools and in government-aided schools with special education programmes.

There are three types of special education settings identified in the Malaysian education system which are special schools, integrated programmes and inclusive programmes. An integrated program, forms part of the mainstream school, is aimed at maximizing the social interaction between pupils with special education needs and their mainstream peers (Nordin, 2001). On the other hand, inclusive special education program allows pupils with special education needs to be included and to receive instructions within a mainstream class which is proven to have positive results as concluded by several researches (Ali, Ramlee, $\&$ Jelas, 2006). Identifying different categories of special needs allows schools to recognize the education programmes that suits the special children's needs. This study however only focuses on the special education integrated programme or known as PPKI. 
According to the MOE's Manual Operation for PPKI, great considerations are taken into account before operating PPKI in schools that includes the parents' or guardian's application, pupil projections, the needs for Special Education teacher, physical infrastructure of classrooms, equipment and teaching materials.

Pupils with special education needs commonly require easy accessibility and barrier-free environment in the school area to ease their movements and wayfinding within the school compound. Supporting school facilities such as the library, computer laboratory, music room among others should be equally accessible. Accessible school facility should be a priority even though the number of pupils with special education needs is significantly less in comparison to the number of normal mainstream pupils. However, it is noted that the recorded number of special education pupils has been increasing over the years (Jelas \& Ali, 2014).

\section{SCHOOL CRITERIA}

School choice is the right to express a preference for specific schools (Burgees, Greaves, Vignoles, \& Wilson, 2014). Parents' satisfaction is a rather subjective factor in the decision making, because it is the overall considerations of all criteria upon taking into account all the possible pros and cons of available options (ISCA, 2008).

The ideal school distance is stipulated in the planning and design guidelines for educational facilities published by the Federal Department of Town and Country Planning Peninsular Malaysia. The school location and the school distance are significantly related in determining the home to school travelling mode (Adepoju \& Oluchukwu, 2011; Yusuf \& Adigun, 2010; Ibrahim, Osman, $\&$ Bachok, 2014). Despite the school distance influencing the mode of transport, route safety remains the top concern in deciding the mode of transport (Lee, Zhu, Yoon, \& Varni, 2013). Regrettably, children with special education needs may require to travel further than those of mainstream programmes due to the limited number of schools that suits their particular education needs (Easton \& Ferrari, 2015). Some of these special pupils are prone to greater risk of injuries and fatality in the event of an accident (Graham, Keys, McMahon, \& Brubacher 2014).

Previous studies show that the school location is one of the top most important factor that is also a variable that affects the pupils' academic performance (Adepoju \& Oluchukwu, 2011; Bukhari, Rodzi, \& Noordin, 2010). In general, there are other factors that may influence pupils' academic performance. A study done in the US on educational placement shows that schools in urban districts tend to have higher enrollment rate that influences the time spend in general education (Brock \& Schaefer, 2015). In the case of those with special needs, their overall performance may be greatly influenced by 
Muhammad Faris Abdullah, Ainul Ashiqin Ahmad Shuhaimi, Mariana Mohamed Osman, \& Noor Suzilawati Rabe Factors Influencing Parents in Selecting School for Children with Special Education Needs

anxiety, lack of self-confidence, negative self-concept, personal inadequacy and maladjustments (Adeyemi, 2011). In consideration of these factors, parents tend to less emphasize on the academic performance of their special children.

Since not every pupils are ready to start on academic work at a young age, a special environment is recommended for the children with special needs that provides them special curriculum that suits their social and vocational needs (Rahaman, 2014; Schneider, 2003; Bhattacharya, 2016). The key to effective libraries and facilities is to include the involvement of teachers with special education backgrounds (Abrizah \& Ahmad, 2010).

Other than specialized academic materials, pupils with different disabilities may require physical assistance such as ramps, handrail, signage and many more. Educational facilities should provide a safe and secure environment for all pupils especially for the special need pupils where every parent is confident in allowing their child to live independently (Rahaman, 2014). Educational facility should be able to provide sufficient resources (Abrizah \& Ahmad, 2010), for example, school spaces and environment need to be safe and secure for both the pupils and the teachers, so as to feel calm, motivated, active and confident to move around.

The appropriate ratio for teachers in integrated special education programmes should be 1.5 teachers to 6.5 pupils or maximum of seven (7) pupils per class. Small group learning is found to be more conducive, secure and tolerant of special pupils (Meynert, 2014). Large classes may discourage involvement, provides opportunities for social lazing with pupils playing a less active role in the learning process (Leufer, 2007).

Parental income greatly affects the parents' ability to support their child in their educational pursuit (Coelli, 2011; Huang, Guo, Kim, \& Sherraden 2010). The paternal and the maternal income do however have different influence on the child‘s education costs (Dunn, Cole, \& Estrada, 2009).

\section{METHODOLOGY}

The factors addressed in this paper was based on literature reviews. The reviews serve as a purpose to indicate and discuss significant issues and to justify findings in the attempt to explain and support the findings from a questionnaire survey as data-collection method. In relation to this study, literature review acts as an important tool involving readings from numerous important materials gathered from, journals, public papers and media on issues relating to school selection.

The factors included in the questionnaire are made into a simple and clear form that would ease the respondents in answering the questionnaire survey. For this study in particular, the targeted respondents are the parents of children with special education needs that are enrolled into PPKI. Data collected is analysed using the RII. 
The primary data collection involves questionnaire survey in order to obtain information in regards to the study. The questionnaire consists of five main sections:
i. Section A: Parent's Background
ii. Section B: Child's Background
iii. Section C: Access to Special Education Facilities
iv. Section D: Parents' School Criteria
v. Section E: Issues on Special Education Programmes

However, this paper solely focus on the school criteria as well as the issues surrounding the special education programme. The data collection stage was conducted within a 3 months period, from Mac 2016 to June 2016. A total of 300 questionnaires were distributed among parents in Gombak district within the data collection period. However, only a total of 134 questionnaires were returned with complete answers.

Then, semi-structured interviews with 12 PPKI teachers as the key informants were conducted to validate the survey data. Teachers were among PPKI vice-principals and class teachers, the key informants were asked to rank the criteria of parental preferences based on their experiences. Later in the interview questions, key informants were enquired to summarise arising issues in regard to the current special education programme.

\section{FINDINGS}

Seven criterias were identified and applied into the study. Parents were asked to rank these criteria according to their preferences, concerning their children with special needs. The seven criteria are (i) location, (ii) distance, (iii) school environment, (iv) school facilities, (v) teacher-pupil ratio, (vi) academic performance and (vii) education cost. Respondents were asked to rank one (1) as the most important criteria until seven (7) as the least important criteria.

RII was calculated to analyse the responses. The RII is a method that determines the relative importance of the factors of preference in decisionmaking in selecting school.

Table 1 School Criteria from Survey

\begin{tabular}{lccc}
\hline Criteria & Score & RII & Rank \\
\hline School Facility & 635 & 0.677 & 1 \\
School Environment & 612 & 0.652 & 2 \\
School Distance & 595 & 0.634 & 3 \\
Academic Performance & 580 & 0.618 & 4 \\
School Location & 556 & 0.593 & 5 \\
Teacher-Pupil Ratio & 403 & 0.430 & 6 \\
Education Cost & 370 & 0.394 & 7 \\
\hline Source: Primary Data (2016) & & &
\end{tabular}


Muhammad Faris Abdullah, Ainul Ashiqin Ahmad Shuhaimi, Mariana Mohamed Osman, \& Noor Suzilawati Rabe Factors Influencing Parents in Selecting School for Children with Special Education Needs

Based on the findings, the school facility was chosen as the most important criteria for parents in selecting school to enrol their special children, with the RII scores of 0.677 which has been stated in the Table.1. This is followed by the school environment with RII scores of 0.652 , school distance with RII score of 0.634 , academic performance with RII scores of 0.618 , school location with RII scores of 0.593 and teacher-pupil ratio with RII scores of 0.430 . The education cost ranked as the least importance criteria in school selection with the lowest RII scores of 0.394 .

Table 2 School Criteria from 12 Key Informants

\begin{tabular}{lccc}
\hline Criteria & Score & RII & Rank \\
\hline School Facility & 65 & 0.774 & 1 \\
School Location & 61 & 0.726 & 2 \\
School Distance & 58 & 0.690 & 3 \\
School Environment & 50 & 0.595 & 4 \\
Teacher-Pupil Ratio & 42 & 0.500 & 5 \\
Academic Performance & 41 & 0.488 & 6 \\
Education Cost & 19 & 0.226 & 7 \\
\hline
\end{tabular}

Source: Primary Data (2016)

Table 2 shows the findings of the semi structured interviews, the school facility was chosen as the most preferred criteria for parents in choosing a school to enrol their special children, with the RII scores of 0.774 . This is followed by the school location with RII scores of 0.726 , school distance with RII score of 0.690 , school environment with RII scores of 0.595 , teacher-pupil ratio with RII scores of 0.500 and academic performance with RII scores of 0.488 . The education cost ranked as the least importance criteria in school selection with the lowest RII scores of 0.226 .

In the final section of the questionnaire survey, parents and key informants were enquire if there were issues encountered in selecting school and other arising issue in regards to the special education programme. The common problems faced by parents includes (i) that there are limited number of schools that cater to children with special needs, and (ii) some of the parents had to consider and be referred to several schools before registering their children into a school.

From the perspective of the key informants, the common issues in regards to the special education programmes includes (i) the limited number of schools offering suitable PPKI programmes, (ii) the school distance is further than the desirable distance, (iii) the number or the size of the facilities have not been improved to meet the population, other issues include the difficulty in standardizing the pupils' teaching and learning methodology due to their different needs and challenges and that the variance of development modules are limited. 
PLANNING MALAYSIA

Journal of the Malaysia Institute of Planners (2018)

\section{DISCUSSION}

The research aims to determine parents' criteria in selecting public schools with PPKI that suits their children's special needs. The findings from the interview are used to validate the survey's findings. There are two main objectives to this study, the first is to analyse the factors influencing the decision of parents in selecting school for their special children. A conclusion drawn based on the findings is that the school facility is top most influential factor in selecting school for children with special education needs. Parents prefer schools with suitable and good facility provision that is able to support their special need children. The school facility has a significant effect on the pupils' performance, which explains parents' preference.

The school facility is positively correlated with the pupils' performance according to several studies. Adequate infrastructure and facilities becomes the basic need for the development of children with special needs. It has been discussed that pupils with special education needs prefers to engagre their senses for better focus and learning capacity. One form of facility provision may be suitable for average child, but may be unfit for children with special needs. The PPKI aims to educate these special pupils into developing basic set of skills such as self-management skills, communication skills, cooking skills to name a few. As a mean of support to develop these skills, proper and well equipped facility should be provided.

In addition, a conducive school environment which is a reflection of a good school facility is the second top most important criteria for parents. The school environment includes the overall conducive learning and teaching as well as a safe and secure surrounding. When most parents consider the school facility to be the most important factor in selecting school for their special children, parents are willing to travel at a greater distance if the chosen school provides better school facilities. Primary schools should be within $800 \mathrm{~m}$ radius from home while secondary schools should be within $1.6 \mathrm{~km}$ radius. However, it is difficult for PPKI schools to meet this stipulated buffer zone due to the fact that identifying new PPKI schools are not as specified as public mainstream schools. The setting for special education programmes are not pre planned like the public schools. Commonly, special programmes came in later upon the operation of the public schools.

Academic performance in most studies influences parents decision in selecting school for their children. However, in the case of these special education needs children, parents consider the children's ability for self care and management as a greater importance than just achieving top academic performance. Majority of the children with special education needs are among those with learning problems that explains, academic achievements as a bonus and not as the top priority. Especially for children with Down syndrome, hearing 
Muhammad Faris Abdullah, Ainul Ashiqin Ahmad Shuhaimi, Mariana Mohamed Osman, \& Noor Suzilawati Rabe Factors Influencing Parents in Selecting School for Children with Special Education Needs

impairment, the ability to communicate and to relate to their surroundings is of greater importance than the academic performance.

The second objective is to assess the issues faced by parents in selecting school for their special children. Based on the findings, the most common issue encountered by parents is the limited number of schools that provides suitable programme for children's special needs. The school distance have become a corresponding issue upon selecting a suitable public PPKI school. Distance to travel daily has a significant impact on the expenses and time. Distance becomes an issue for a parents with lower income group and those that cannot afford the time to travel out of their way to send of their child to school. Options are not available for all parents. The school distance and the location affects the mode of transportation, which explains the contribution of the school distance as part of the common issue in selecting school for children with special needs.

Other issue includes is the size of the education facility provided. The number of pupils enrolled into PPKI have been increasing over the years, however, the facilities provided have not been upgraded to meet the growing number of pupils. Schools find most PPKI classes to be overcrowded, where the number of pupils within a classroom exceeded the optimum number of maximum seven (7) pupils for each teacher. Due to the growing number of students and the limited number of schools providing a specified PPKI category, parents may have to be referred to several schools, before deciding which school is able to provide the resources required by the child for their learning progress. Due to the limited number of programmes offered, some parents were advised to enroll their children into other school which may not be their first choice. Parents' first choices would usually be schools with the best facilities that suits the child's special education needs as well as acceptable distance and desirable location. Being advised to consider other options may not be ideal for some of the parents.

\section{RECOMMENDATION}

PPKI school siting should be as detailed and specific like public mainstream schools. The irregular distribution of PPKI schools within a district resulted in difficulties among parents in selecting schools for their special children. PPKI schools are often found to be overcrowded due to the limited number of schools offering PPKI within a district. The number of schools provided should be able to cater to the increasing number of pupils registered into the programme.

\section{CONCLUSION}

This overview on the factors influencing parents is significant towards realizing better planning and facilities provision for special education especially in public schools. Adequate infrastructure and facilities becomes crucial as a basic support for the development of children with special needs. Quality educational facility 
for special children should be one of MOE's top priority in education development aligned with its education principles that is to provide quality and equal education access for all children.

\section{REFERENCES}

Abrizah, A. \& Ahmad, R. (2010). Systemic barriers: The challenges in the provision of inclusive school libraries in Malaysia. Malaysian Journal of Library \& Information Science, 15(2), 19-40.

Adepoju, T. L. \& Oluchukwu, E. E. (2011). A study of secondary school students' academic performance at the Senior School Certificate Examinations and implications for educational planning and policy in Nigeria. African Research Review, 5(6), 314-333.

Adeyemi, T. O. (2011). A comparative study of students' academic performance in public examinations in secondary schools in Ondo and Ekiti States, Nigeria. Current Research Journal of Economic Theory, 3(2), 36-42.

Ali, M. M., Ramlee, M., \& Jelas, Z. M. (2006). An empirical study on teachers' perceptions towards inclusive education in Malaysia. International Journal of Special Education, 21(3), 36-44.

Bhattacharya, P. (2016). Comparison of educational facilities of mentally challenged children of special school and government school in Kolkata. The International Journal of Indian Psychology, 3(2), 132-149.

Brock, M. E. \& Schaefer, J. M. (2015). Location matters: Geographic location and educational placement of students with developmental disabilities. Research and Practice for Persons with Severe Disabilities, 40(2), 154-164.

Bukhari, Z., Rodzi A. M., \& Noordin, A. (2010). Spatial multi-criteria decision analysis for safe school site selection. International Geoinformatics Research and Development Journal, 1(2), 1-14.

Burgess, S., Greaves, E., Vignoles, A., \& Wilson, D. (2014). What parents want: School preferences and school choice. The Economic Journal, 125(587), 1262-1289.

Coelli, M. B. (2011). Parental job loss and the education enrollment of youth. Labour Economics, 18(1), 25-35.

Dunn, M. W., Cole, C. M., \& Estrada, A. (2009). Referral criteria for special education: General education teachers' perspectives in Canada and the United States of America. Rural Special Education Quarterly, 28(1), 28-37.

Easton, S. \& Ferrari, E. (2015). Children's travel to school - the interaction of individual, neighbourhood and school factors. Transport Policy, 44, 9-18.

Graham, B. C., Keys, C. B., McMahon, S. D., \& Brubacher, M. R. (2014). Transportation challenges for urban students with disabilities: Parent perspectives. Journal of Prevention \& Intervention in the Community, 42(1), 45-57.

Huang, J., Guo, B., Kim, Y., \& Sherraden, M. (2010). Parental income, assets, borrowing constraints and children's post-secondary education. Children and Youth Services Review, 32(4), 585-594.

Ibrahim, N. M., Osman, M. M., \& Bachok, S. (2014). Public school development and planning: Parents' criteria of selecting public school in Gombak District. Procedia - Social and Behavioral Sciences, 153, 274-285. 
Muhammad Faris Abdullah, Ainul Ashiqin Ahmad Shuhaimi, Mariana Mohamed Osman, \& Noor Suzilawati Rabe Factors Influencing Parents in Selecting School for Children with Special Education Needs

Independent Schools council of Australia [ISCA] (2008). Factors affecting school choice. Retrieved from http://isca.edu.au/blog/factors-influencing-school-choice/.

Jelas, Z. M. \& Ali, M. M. (2014). Inclusive education in Malaysia: Policy and practice. International Journal of Inclusive Education, 18(10), 991-1003.

Lee, C., Zhu, X., Yoon, J., \& Varni, J. W. (2013). Beyond distance: Children's school travel mode choice. Annals of Behavioral Medcine, 45(Suppl 1), S55-S67.

Leufer, T. (2007). Students' perception of the learning experience in a large class environment. Nursing Education Perspectives, 28(6), 322-326.

Mat, M. N. A. (2001, November). Developing special education in each country and enhancing international mutual cooperation among countries in the Asia-Pacific region. 21st APEID Regional Seminar on Special Education. November 8-23, 2001, Tokyo, Japan.

Meynert, M. J. (2014). Inclusive education and perceptions of learning facilitators of children with special needs in a school in Sweden. International Journal of Special Education, 29(2), 35-52.

Rahaman, F. (2014). Inclusive educational environment for children with autism in Malaysian primary schools: Addressing the issues of wayfinding (Master thesis). International Islamic University Malaysia, Kuala Lumpur, Malaysia.

Schneider, M. (2003). Linking school facility to teacher satisfaction and success. Washington D. C.: National Clearinghouse for Educational Facilities.

Yusuf, M. A. \& Adigun, J. T. (2010). The influence of school sex, location and type on students' academic performance. International Journal of Educational Sciences, 2(2), 81-85. 